\title{
Scotland, Scots AND THE Boundaries OF THE INDian OCEAN World
}

\author{
Andrew MacKillop \\ University of Glasgow
}

In introducing four articles on Scottish society and the Indian Ocean World, it is worth acknowledging at the outset some of the broader questions that such a nationally defined framing could reasonably prompt. After all, centring the nation - and a small, northern European nation at that - might seem to run counter to the whole underlying philosophy behind the Indian Ocean studies approach. Ever since scholars sought to conceive of an oceanic zone of interconnection, exchange and mutual influence, a key emphasis in Indian Ocean histories has been the theme of internal coherence and 'unity.' Debates over what constituted this unity have ranged from climatic determinants (especially the influence of monsoon weather systems), the extent of maritime influences upon coastal littorals and hinterlands, the impact of different socio-religious zones, to the consequences of shared natural resources and technologies as well as patterns of commodity and human mobility. ${ }^{1}$ Territorial and national boundaries - not least because of the European assumptions inherent such concepts - are considered secondary to trans-regional processes of interaction and exposure to a broadly common set of climatic, environmental, human and socio-economic dynamics. If the objective is understanding connectivity across the vast area between the South China Seas and eastern Africa, it is reasonable to ask what precisely Scottish-based examples can contribute? The privileging of a country so obviously detached in climatic, geographic and socio-cultural terms might seem to mark the return of Eurocentrism via Europe's own 'periphery.'

Viewed in this way, Scottish themed material represents in microcosm the wider issue of how to best incorporate the European presence and its legacies into a holistic assessment of the Indian Ocean World throughout the colonial era. Central to

\footnotetext{
${ }^{1}$ K.N. Chaudhuri, India and Civilisation in the Indian Ocean: An economic history from the rise of Islam to 1750 (Cambridge: Cambridge University Press, 1985), 18-32; Michael N. Pearson, The Indian Ocean (London: Routledge, 2003), 3-7.

${ }^{2}$ For discussion of Scotland's shifting status from Europe's 'periphery' to 'core' via union and economic integration with England and Wales, see: Immanuel Wallerstein, The Modern World System II: Mercantilism and the consolidation of the European World Economy, 1600-1750 (New York: Academic Press, 1980), 251-55, 265.
}

(C) Andrew MacKillop. This is an Open Access article distributed under the terms of the Creative Commons License CC BY NC SA, which permits users to share, use, and remix the material provided they give proper attribution, the use is noncommercial, and any remixes/transformations of the work are shared under the same license as the original. 
consideration of this question is the extent to which the European intrusion marked a major discontinuity in the development of that part of the world and, if so, when? ${ }^{3}$ The alternative reading is that the scale, sophistication and dynamism of the Indian Ocean World's various socio-cultural and economic zones largely absorbed the newcomers into pre-existing frameworks. As a result Europeans were limited in their ability to fundamentally reshape conditions in the societies bounding the Indian Ocean before c. $1800 \mathrm{CE}^{4}$

It is in this context of an ongoing re-evaluation of European influences that evidence derived from Scotland has wider resonances beyond the country's own national and diasporic histories. ${ }^{5}$ The timing of the country's increasing connections to the societies of the Indian Ocean fit within a discernible if still relatively underexplored movement eastwards by northern Europe which began picking up momentum in the 1660s to 1730s. ${ }^{6}$ Yet it is important to stress that even by the end of this period Scotland's direct experience of the eastern hemisphere was decidedly limited. With the exception of one or two vessels sent into eastern waters in the early 1700s, the pre-1707 kingdom never operated as an independent trading or colonial power. The Scottish profile took the form of individual Scots or networks of Scots, not a formally organised, national project in the mode of the Portuguese, Dutch, French or English. Neither did Scotland sustain the smaller-scale commercial operations of the Danes or Swedes, two northern European countries whose geography and populations make them more realistic comparators. ${ }^{7}$ The country's trajectory within the broader phenomenon of European expansion meant it was almost 250 years after the arrival of the Portuguese before Scots began appearing in the Indian Ocean theatre in any meaningful numbers. Only active from the consolidation phase of European influence, Scots were, along with the Irish and Welsh, subsumed into the English East India Company's noticeably cosmopolitan workforce. ${ }^{8}$

\footnotetext{
${ }^{3}$ Kenneth Pomeranz, The Great Divergence. China, Europe and the making of the modern world economy (Princeton: Princeton University Press, 2000), 100-191.

${ }^{4}$ For an effective summary and reconsideration of this central theme, see: Prasannan Parthasarathi and Giorgio Riello, "The Indian Ocean in the long eighteenth century,” Eighteenth-Century Studies, 48, 1 (2014), 1-19.

${ }^{5}$ For an important consideration of the relationship between national and diasporic histories in a Scottish context, see: Catriona M.M. Macdonald, "Imagining the Scottish diaspora: Emigration and transnational literature in the late modern period," Britain and the World, 5, 1 (2012), pp.12-42.

${ }^{6}$ Andrew Mackillop, "A North Europe world of tea: Scotland and the tea trade, c.1690-c.1790," in Goods from the East, 1600-1800: Trading Eurasia, eds. Berg Maxine, Felicia Gottmann, Hanna Hodocs, and Chris Nierstrasz (Houndmills: Palgrave MacMillan, 2015), 304-6.

${ }^{7}$ H. Furber, Rival Empires of Trade in the Orient, 1600-1800 (Oxford: Oxford University Press, 1976), 210-7.

${ }^{8}$ Andrew Mackillop, Human Capital and Empire: Scotland, Ireland, Wales and British Imperialism in Asia, c.1690-c.1820 (Manchester: Manchester University Press, 2021), 83-191; G. K. McGilvary, East India Patronage and the British State: The Scottish elite and politics in the eighteenth century (London: Tauris, 2008), 232.
} 
The reality of small-scale migration and comparatively late involvement explains why Scotland and Scots have an understandably marginal profile in explorations of European colonialism in Asia and eastern Africa. The contrast is at its clearest if compared to the country's relative prominence in British Atlantic world literature. ${ }^{9}$ While histories of the Indian Ocean are familiar with the presence of the Portuguese, the Spanish, the French, the Dutch and the English, they are far less focused on the Danish-Norwegians, Swedes, or even the large number of soldiers and sailors from German speaking lands employed by the Dutch East India Company. ${ }^{10}$ Along with these other nationalities, the arrival in Asia and eastern Africa of increasing numbers of Scots formed part of a marked demographic diversification of Europeans. Like the example of other, less high-profile or seemingly relevant parts of the continent, Scotland warns against an overly monolithic reading of colonial-era Europe.

Besides offering a recalibration of the human element of the European intrusion, there are other historiographic and conceptual trends in British imperial and Indian Ocean studies which create new interpretative relevance for Scottish evidence. These span the global to the quotidian. At their most expansive, such reconsiderations include a greater focus on the mutually influencing connections between the Atlantic basin and the societies fringing the Indian Ocean. Interlinking these two world zones is rightly seen as key to progressing a holistic and less Euro-centric global history. ${ }^{11}$ If the Indian Ocean World's boundaries or, perhaps less rigidly, its malleable spheres of influence are to be extended to involvement in its Atlantic equivalent, then Scotland has the potential to become much more relevant. Another way of thinking about these efforts to interlink the two 'worlds' is to recall the crucial distinction between what has been described as the history which

\footnotetext{
${ }^{9}$ Alison Games, "Migration," in The British Atlantic World, 1500-1800, eds. David Armitage and Michael J. Braddick (Houndsmills: Palgrave MacMillan, 2009), 33-37.

${ }^{10}$ O. Feldæk, 'The organisation of the Danish East India, West India \& Guinea Companies in the $17^{\text {th }} \& 18^{\text {th }}$ Centuries," in Companies and Trade: Essays on overseas trading companies during the Ancien Regime, eds. L. Blussé \& F. Gaastra (Leiden: Leiden University Press, 1981); C. Konickx, The First and Second Charter of the Swedish East India Company, 1731-1766 (Kortrijk: Van Ghemmert, 1980), 30-36; S. T. Kjellberg, Svenska Ostindiska Compagnierna, 1731-1813 (Malmö: Aktiebolaget Allhem, 1974), 133, 316; R. van Gelder, Het Oost-Indisch avantuur: Duitsers in dienst can de VOC, 1600-1800 (Nijmegan: Sun, 1997), 40-1

${ }^{11}$ J. Bohorquez, "Linking the Atlantic and Indian Oceans: Asian textiles, Spanish silver, global capital, and the financing of the Portuguese-Brazilian slave trade (c.1760-1808)," Journal of Global History, 15 (2020), 22; Prasannan Parthasarathi, "Textiles and silver: The Indian Ocean in a global frame," in Textile Trades, Consumer Cultures, and the Material Worlds of the Indian Ocean: An Ocean of cloth, eds. Pedro Machado, Sarah Fee, and Gwyn Campbell (London: Palgrave Macmillan, 2018), 30-38; P.J. Stern, "British Asia and the British Atlantic: Comparisons and connections," William and Mary Quarterly, 63 (2006), 693-712; H.V. Bowen, Elizabeth Mancke, and John G. Reid, "Introduction: Britain's oceanic empire," in Britain's Ocean Empire: Atlantic and India Ocean Worlds, c1550-1850, eds. H.V. Bowen, Elizabeth Mancke, and John G. Reid (Cambridge: Cambridge University Press, 2012), 1-11.
} 
occurred 'in' the Indian Ocean as opposed to the history 'of' the Indian Ocean. ${ }^{12}$ The latter is a much more expansive and open-ended conception of how and where its influence was present and important. This understanding acknowledges the zone's internal connectiveness while pointing to how these characteristics enabled the peoples and products of the Indian Ocean, as well as ideas from and about that part of the world, to travel well beyond its geographic boundaries.

Scottish society aligns closely to both these histories. As the four articles of this special feature demonstrate, Scots individually and collectively were active 'in' the Indian Ocean World. This involvement occurred on a noticeably compressed timescale. From statistically irrelevant numbers as late as the 1720s, within one hundred years Scots were evident from its western frontier in Africa to its eastern edge in ports such as Benkulen and Canton. Moreover, in certain geographic regions, including post-1800 Ceylon, or in certain professions such as the English East India Company's military and medical services, Scots could be found in numbers disproportionate to the country's relatively small share of the British and Irish Isles' population. ${ }^{13}$ As both Elbourne and Gooding's articles discuss, Scots such as Thomas Pringle or David Livingstone could be settlers, 'liberal' intellectuals and anti-slavery missionaries. They combined seemingly contradictory or at least tension-ridden roles, all the while exhibiting a practical and ideological commitment to British imperialism, as well as a dismissive superiority towards the peoples and societies they encountered.

The multiplicity of roles exhibited by Pringle and Livingstone as well as their complicity in British colonialism highlight the value in critically revisiting the hagiographical traditions that surround certain prominent personalities. By situating their subjects more fully in their own geographic and ideological worlds, and by exploring Livingstone's contemporary legacies in the cultural politics of East and Central Africa, Elbourne and Gooding offer important critiques of the tendency (not least in Scotland) towards a celebratory attitude towards such individuals. ${ }^{14}$ Meanwhile, MacKenzie and Mackillop's contributions consider how and with what consequences the Scottish profile evolved beyond just a collection of individuals. While always a tiny numeric presence when set in the context of local populations, Scots were a substantial minority within the

\footnotetext{
${ }^{12}$ Pearson, The Indian Ocean, 7.

${ }^{13}$ P. J. Marshall, "British society in India under the East India Company," Modern Asian Studies, 31 (1997), 90-1.

${ }^{14}$ For discussion of how the historiography of Scots in the British Empire developed an early and persistent tendency towards exceptionalising and even celebrating the country and its people's contribution to imperialism, see: John M. MacKenzie and T.M. Devine, "Introduction," in The Oxford History of the British Empire: Scotland and the British Empire, eds. John M. MacKenzie and T.M. Devine (Oxford: Oxford University Press, 2011), 10-14.
} 
British colonial community (although always less significant than the Irish). ${ }^{15}$ As migration increased, so too did familial and social networks. By the 1820s and 1830s these had developed to the extent that it is possible to talk of the emergence of civic Scotland in some of the major settlements in South Asia and in entrepôts such as Singapore and Hong Kong. This process had both informal and formal dimensions, with kinship and family identities augmented by the more institutionalised expressions of Scottishness in the form of the Kirk of Scotland congregations formed in Calcutta, Bombay and Madras, often in the face of considerable Church of England disquiet. ${ }^{16}$ In this way, Scottish society, and not just individual Scots, migrated into the Indian Ocean World. The traces of this more structural connection can be found in the patterns of legal and financial networking considered by Mackillop and in the emergence of distinctively Scottish spaces of memorialisation and religious infrastructure discussed by MacKenzie.

These developments point to the potential value of using Scots as an example of diasporic dynamics within a colonising elite. The Journal of Indian Ocean World Studies has recently considered the question of how themes of 'diaspora' can be productively revisited within the distinctive framework of Indian Ocean historiography. In an effort to ensure the concept of diaspora is not used as a theoretically vague shorthand for a community of migrants, there is a renewed emphasis on how groups such as the Hadrami, Gujarati, Tamils and Chinese moved across oceanic distances while retaining ' .... a sense of cohesion and of collective identity that is of both symbolic and practical significance, across time and space. ${ }^{17}$ While care is needed when drawing too close a parallel between Scots and these intra-Indian Ocean traditions of mobility, some of the same themes of enduring connection are evident. One obvious way that those Scots arriving in places such as eastern Africa, Ceylon or Calcutta do not fit the model of diaspora is the lack of force. Reflecting the concept's original association with understanding Jewish History, diaspora is strongly associated with coercion, with a people or nation driven out of their homelands

\footnotetext{
15 Thomas Bartlett, "The Irish soldier in India, 1750-1947," in Ireland and India: Connections, comparisons, contrasts, eds. Michael Holmes and Denis Holmes (Limerick: Blackwater Press, 1997), 12-28; Barry Crosbie, Irish Imperial Networks: Migration, social communication and exchange in nineteenth-century India (Cambridge: Cambridge University Press, 2012), 68-98.

${ }^{16}$ T. Beultmann, "Ethnic associationalism and networking among the Scots in Asia: A longitudinal comparison, c. 1870 to the present," in The Scottish Experience in Asia, c. 1700 to the Present, eds., T.M. Devine and Angela McCarthy (Cham: Springer, 2017), 261; Joseph Sramek, "Rethinking Britishness: Religion and debates about the "nation" among Britons in Company India, 1813-1857,” Journal of British Studies, 54 (2015), 822-43.

${ }^{17}$ Iain Walker and Martin Slama, "The Indian Ocean as a diasporic space: A conceptual introduction," Journal of Indian Ocean World Studies, 4, 2 (2021), 76-90 (quotation from p. 80).
} 
and seeking or imagining their eventual return. ${ }^{18}$ While ordinary European seamen and soldiers, Scots included, migrating to the Asian hemisphere of Europe's expansion often had limited economic or social options, they retained levels of agency that do not fit at all well with the original conception of diaspora.

If viewed as sojourners, however - that is as migrants moving to an overseas destination with the intention of returning home at a later date - then such individuals and those further up the colonial elite do align more closely to the emphasis on retaining a connection to a place of origin. ${ }^{19}$ The Scots explored here conform closely to this model of mobility. They demonstrate how colonising groups often interacted with peoples and societies across the Indian Ocean World in ways that were clearly understood or intended as time limited. There is a pronounced looking backwards towards 'home' among many of the Scots discussed in the four articles. The patterns of financial repatriation discussed by Mackillop show a clear alignment towards the United Kingdom and to the buttressing of family status and material resources in Scotland. Even those who did not return often sought to signal their desire for remaining emotionally connected to their place of origin. MacKenzie's consideration of a Scottish Deathscape highlights how cultures of memorialisation embedded Scots as members of the British colonial elite while ideas of family, kinship and locality in Scotland enabled them to permanently display their individuality and distinctiveness.

If evidence derived from Scottish examples show the complex cultural politics of the Europeans in Asia, it is equally the case that the articles point to the wider history of the Indian Ocean World far beyond its own geographic boundaries. While Scotland's location placed it at the centre of Europe's expansion into the Atlantic World, it arguably marginalised the country in terms of colonialism in Asia and eastern Africa. Yet it is testimony to the gravitational pull of the societies fringing the Indian Ocean that their influence swept across Scotland in increasingly profound ways from the later seventeenth century onwards. The country's lack of direct contact before c.1700 CE meant that when these influences did appear they are arguably easier to trace when compared with other European societies whose exposure was more organic and prolonged. ${ }^{20}$ There is of course a sophisticated literature on commodities, luxuries and consumption which confirms how products from across the Indian Ocean World transformed Europe in the centuries after

\footnotetext{
${ }^{18}$ For discussion of the concept and the development of a historiography of diaspora, see: Tanja Bueltmann, Andrew Hinson and Graeme Morton, The Scottish Diaspora (Edinburgh: Edinburgh University Press, 2013), 16-33.

${ }^{19}$ Marjory Harper and Steven Constantine, The Oxford History of the British Empire: Migration and empire (Oxford: Oxford University Press, 2010), 307-37.

${ }^{20}$ Mackillop, Human Capital, 30.
} 
c.1500 CE. ${ }^{21}$ Scotland was no different in this respect, experiencing a wave of consumables, from calicos, spices and teas that impacted the entire country and social hierarchy. The articles here, however, shift perspective from this indirect, largely material culture orientated understanding towards a familial and culturally inflected emphasis. Both MacKenzie and Mackillop's contributions stress how transhemispheric migration forced the globalisation of Scottish kin networks. A direct consequence of this expansion overseas was the defence of kinship and even of Scottishness itself in new ways. One way of achieving this involved the adoption of racialised understandings of what constituted the idealised family. In these different ways the influence of the Indian Ocean reached deep into the domestic, familial, and socio-cultural development of Scottish society. Scotland may have been present in the Indian Ocean World, but the reverse was equally true. As Gooding argues, the cultural repercussions of these overlaps persist right into the present. David Livingstone's idealisation in the later nineteenth and twentieth century as the embodiment of Britain's Christian, commercial and 'civilising' empire continues to shape contemporary cultural strategies in Malawi and Tanzania.

There were equally significant if less obvious counterflowing influences in Scotland. Pringle's experiences in South Africa confirmed for him in new and powerful ways the stadial thinking that was such a hallmark of his Scottish education. Meanwhile, his various publications confirmed for his wider readership their understandings of stereotypical Scottish migrants and the need in colonial societies for the attributes of literacy and godly virtue, which they supposedly embodied. Be it through the diffusion into family life of race and colour consciousness or the reaffirmation of putative national characteristics, the Indian Ocean World shaped Scotland just as surely as the other way around.

The disparity in scale between Scotland and the Indian Ocean World is such that care is needed when placing them in the same frame. The obvious differences - of climate, geography, history, culture, and the experience of European colonialism - warn against easy comparisons and connections. Yet the articles reveal that connections and mutual influencing occurred at multiple levels and continue into the twenty-first century. Above all, taken collectively, they point to the need to rethink the oceanic boundaries of Scotland

\footnotetext{
${ }^{21}$ Jan de Vries, The Industrious Revolution: Consumer behavior and the household economy, 1650 to the present (Cambridge: Cambridge University Press, 2008), 43-57; Christopher J. Berry, The Idea of Luxury: A conceptual and historical investigation (Cambridge: Cambridge University Press, 1994), 101-2, 126-73; Maxine Berg, Luxury and Pleasure in Eighteenth-Century Britain (Oxford: Oxford University Press, 2005), 6-7, 29-39.
} 
while using multiple approaches to better understand the capacity of the Indian Ocean World to influence societies on the other side of the planet. 